\title{
Effects of concentrate level and rapeseed meal supplementation on performance, carcass characteristics, meat quality and valuable cuts of Hereford and Charolais bulls offered grass silage-barley-based rations
}

\author{
Maiju Pesonen ${ }^{1 *}$, Markku Honkavaara ${ }^{2}$, Helena Kämäräinen ${ }^{3}$, Tiina Tolonen ${ }^{4}$, Mari Jaakkola ${ }^{4}$, Vesa Virtanen ${ }^{4}$ \\ and Arto Huuskonen ${ }^{1}$ \\ ${ }^{1}$ MTT Agrifood Research Finland, Animal Production Research, Fl-92400 Ruukki, Finland \\ ${ }^{2}$ Finnish Meat Research Institute, P.O. Box 56, FI-13101, Hämeenlinna, Finland \\ ${ }^{3}$ University of Eastern Finland, Department of Biosciences, P.O. Box 1627, Fl-70211 Kuopio, Finland \\ ${ }^{4}$ University of Oulu, Kajaani University Consortium, CEMIS-Oulu, Salmelantie 43, FI-88600 Sotkamo, Finland \\ e-mail: maiju.pesonen@mtt.fi
}

\begin{abstract}
The objectives of this experiment with Hereford ( $\mathrm{Hf}$ ) and Charolais (Ch) bulls offered grass silage-based diets were to determine the effects on performance, carcass traits and meat quality of the proportion of concentrate in the diet, and the inclusion of rapeseed meal (RSM) in the barley-based concentrate. The two concentrate proportions were 200 and $500 \mathrm{~g} \mathrm{~kg}^{-1}$ dry matter, fed without or with RSM. The Ch bulls tended to achieve higher gain, produced less fat, had a higher percentage of meat from high-priced joints and had a lower degree of marbling in their meat compared to the $\mathrm{Hf}$ bulls. Dry matter and energy intakes, growth performance and carcass conformation improved with increasing concentrate level. Intake parameters and conformation improved more with the Ch bulls than with the $\mathrm{Hf}$ bulls as a consequence of increased concentrate allowance. RSM had only limited effects on the performance, carcass traits or meat quality.
\end{abstract}

Key words: beef production, bulls, concentrate level, supplementary protein, performance, eating quality, meat fatty acids

\section{Introduction}

Although beef production in Finland is based mainly on raising dairy bulls, production from beef breed calves is increasing at present. In total, 12 beef breeds are currently kept, and Charolais (Ch) and Hereford (Hf) are the two most frequently used beef breeds. The decrease in the number of dairy cows has diminished the supply of calves for beef production originating from dairy herds. Because the supply of domestic beef has been decreasing, there is nowadays a clear discrepancy between the demand for and supply of domestic beef. Consequently, slaughterhouse pricing favours heavy carcasses and the average carcass weights of slaughtered animals have clearly increased in Finland during recent years. For example, the average carcass weight of slaughtered bulls (including both dairy and beef breeds) increased from $275 \mathrm{~kg}$ (1996) to $335 \mathrm{~kg}$ (2008) in twelve years (Karhula and Kässi 2010). Currently, it is typical that bulls of British beef breeds (Hereford, Angus) are slaughtered in carcass weights near $400 \mathrm{~kg}$ and late maturing beef breeds (Charolais, Simmental) in carcass weights above $400 \mathrm{~kg}$ (Huuskonen et al. 2012).

In intensive beef production, grass silage is typically supplemented with grain to increase the energy and nutrient intake of growing bulls. Rapeseed meal (RSM) is the most important protein feed used in concentrates for cattle. Nowadays many beef producers use protein supplements with grass silage grain- based feedings (Huuskonen 2009a) even though the price of RSM is high compared to those of grain or forages and feeding extra protein increased the $\mathrm{N}$ and $\mathrm{P}$ excretion to the environment (Klopfenstein and Erickson 2002).The effects of both concentrate level and protein supplementation on the performance of growing cattle have been extensively studied. It is well established that good quality silage can support high levels of performance with moderate concentrate supplementation. However, increasing the allowance of concentrate has often improved the growth rate and decreased the days until slaughter (e.g. Huuskonen et al. 2007, Randby et al. 2010). With dairy bulls it was concluded that concentrate with a higher protein concentration than barley grain is not needed when the animals are fed high- or medium-digestibility and restrictively fermented grass silage and barley-based concentrate (Huuskonen et al. 2007, 2008b, Huuskonen 2009b, 2011). Relative to dairy bulls, much less research has been carried out on the feeding of beef bulls and, in fact, there is lack of information on the effects of concentrate proportions and protein supplementation on the performance, carcass traits and meat quality of beef-breed bulls offered typical Finnish grass silage-barley-based rations and slaughtered with high carcass weights. 
Meat quality aspects are receiving considerable attention among consumers. For example, meat colour is an important determinant of the visual appearance of meat, with light coloured beef often being preferred, although some consumers may favour dark beef associating this appearance with a more natural production method (Razminowicz et al. 2006). Tenderness and marbling are important properties of beef for consumers and have been studied widely. Nevertheless, studies on the effects of concentrate level and protein supplementation with grass silage-barley-based rations on eating quality are scarce. In addition, the fatty acid composition of beef has received considerable attention in view of its implications for human health and for meat quality characteristics (De Smet et al. 2004). The objectives of the present experiment with growing $\mathrm{Hf}$ and $\mathrm{Ch}$ bulls were to determine the effects on animal performance, carcass characteristics, valuable cuts, meat quality parameters and fatty acid composition of the Longissimus muscle of (1) the proportion of concentrate in the diet, and (2) the inclusion of RSM in the barley-based concentrate fed in total mixed rations (TMR) when animals are slaughtered at typical Finnish carcass weights.

\section{Materials and methods}

\section{Animals and housing}

The feeding experiment was conducted in the experimental barn of the North Ostrobothnia Research Station of MTT Agrifood Research Finland (Ruukki, $64^{\circ} 44^{\prime} \mathrm{N}, 25^{\circ} 15^{\prime} \mathrm{E}$ ) and included three trials. The first trial started in December 2008, the second in January 2010 and the third in January 2011. The experimental procedures were evaluated and approved by the Animal Care and Use Committee of MTT Agrifood Research Finland. The three feeding trials comprised in total 48 purebred $\mathrm{Hf}$ bulls ( $\mathrm{Hf}$ dams sired by $\mathrm{Hf}$ bulls) and 48 purebred Ch bulls (Ch dams sired by Ch bulls) in order that there were 32 bulls per trial. Diet in vivo digestibility, animal performance (intake and gain) and carcass characteristics (carcass weight, dressing proportion, conformation score and fat score) were determined in all three trials, the meat quality parameters and valuable cuts were measured in the second and third trial. Two bulls were excluded from the study due to several occurrences of bloat, one due to pneumonia and three bulls due to hoof problems. There was no reason to suppose that the diets had caused these problems. The records of the six removed animals were not included in the results.

All the animals, initial live weight (LW) $306 \pm 97.9 \mathrm{~kg}(\mathrm{Hf})$ and $333 \pm 63.1 \mathrm{~kg}(\mathrm{Ch})$, on average, were spring-born calves purchased from commercial suckler herds. During their first summer all the calves had been kept on pasture together with their dams. At the start of the experiment the animals were $195 \pm 55.6$ days old, on average, and there was no difference between breeds. During the feeding experiment the bulls were placed in an insulated barn in adjacent tie-stalls. The width of the stalls was $70-90 \mathrm{~cm}$ for the first four months and $113 \mathrm{~cm}$ until the end of the experiment. The bulls were tied with a collar around the neck, and a $50 \mathrm{~cm}$ long chain was attached to a horizontal bar 40-55 cm above the floor. The floor surface was solid concrete under the forelegs and metal grids under the hind legs. No bedding was used on the floor. Each bull had its own water bowl.

\section{Feeding and experimental design}

The bulls were fed a TMR ad libitum (proportionate refusals of $5 \%$ ). A $2 \times 2 \times 2$ factorial design was used to study the effects of concentrate proportion and RSM inclusion in the barley-based concentrate. Both $\mathrm{Hf}$ and Ch bulls were randomly allotted to the experimental feeding treatments. The two concentrate proportions were 200 (L) and $500(\mathrm{M}) \mathrm{g} \mathrm{kg}^{-1} \mathrm{DM}$, fed without RSM (RSM-) or with RSM (RSM+). The concentrate used was rolled barley. Rapeseed meal was given so that the crude protein (CP) content of the concentrate was raised to $160 \mathrm{~g} \mathrm{~kg}^{-1} \mathrm{DM}$ in the RSM+ diets. Therefore the amount of RSM supplement depended on the CP content of the barley which was measured by chemical analyses. In the RSM- diets the average CP content of the concentrate was $126 \mathrm{~g} \mathrm{~kg}^{-1} \mathrm{DM}$, so the content increased $27 \%$ with RSM supplementation.

The grass silages in all three trials were growth from mixed timothy (Phleum pratense) and meadow fescue (Festuca pratensis) stands and were cut using a mower conditioner, wilted for $5 \mathrm{~h}$, and harvested using a precisionchop forage harvester. The grass silages were ensiled in bunker silos and treated with a formic acid-based additive (AIV-2 Plus: $760 \mathrm{~g}$ formic acid kg-1, $55 \mathrm{~g}$ ammonium formate $\mathrm{kg}^{-1}$, supplied by Kemira Ltd., P.O. Box 171, FI-90101 Oulu, Finland) applied at a rate of 5 litres $\mathrm{t}^{-1}$ of fresh grass. The daily ration for the bulls included also $150 \mathrm{~g}$ of a mineral mixture (A-Rehu Ltd., P.O. Box 908, Fl-60061 Atria, Finland: KasvuApeKivennäinen: Ca 260, P 0, Na 70, Mg $35 \mathrm{~g} \mathrm{~kg}^{-1}$ ). A vitamin mixture (Suomen Rehu Ltd.: Xylitol ADE-Vita: A 2,000,000 IU kg , D $_{3}$ 400,000 IU kg-1 E DL- $\alpha$-tocopheryl acetate $1,000 \mathrm{mg} \mathrm{kg}^{-1}$, E DL- $\alpha$-tocopheryl $900 \mathrm{mg} \mathrm{kg}^{-1}$, Se $10 \mathrm{mg} \mathrm{kg}^{-1}$ ) was given at $50 \mathrm{~g}$ per animal weekly. 


\section{Feed and faecal sampling and analysis}

Silage sub-samples for chemical analyses were taken twice a week, pooled over periods of four weeks and stored at $-20^{\circ} \mathrm{C}$. Thawed samples were analysed for $\mathrm{DM}$, ash, crude protein (CP), ether extracts, neutral detergent fibre (NDF), indigestible NDF (iNDF), starch, silage fermentation quality ( $\mathrm{pH}$, water-soluble carbohydrates [WSC], lactic and formic acids, volatile fatty acids, soluble and ammonia $\mathrm{N}$ content of $\mathrm{N}$ ) and digestible organic matter (DOM) in DM (D value). Concentrate sub-samples were collected weekly, pooled over periods of eight weeks and analysed for DM, ash, CP, ether extracts, NDF, iNDF and starch. The analyses were performed as described by Huuskonen et al. (2008a).

The metabolizable energy (ME) contents of the feeds were calculated according to the Finnish feed tables (MTT 2012). The ME value of the silage was calculated as $0.016 \times D$ value. The ME values of the concentrates were calculated based on concentrations of digestible crude fibre, CP, crude fat and nitrogen-free extract described by MAFF (1984). The digestibility coefficients of the concentrates were taken from the Finnish feed tables (MTT 2012). The supply of amino acids absorbed from the small intestine (AAT) and the protein balance in the rumen (PBV) were calculated according to the Finnish feed tables (MTT 2012).

Because the grass silages used in the feeding experiment came from three different harvests, the chemical compositions and feeding values are also given separately for the three silages in Table 1 . The silages used were of good nutritional quality as indicated by the D value as well as the AAT and CP contents (Table 1). The fermentation characteristics of the silages were also good as indicated by the $\mathrm{pH}$ value and the low concentration of ammonia $\mathrm{N}$ and total acids. The silages used were restrictively fermented with high residual WSC concentration and low lactic acid concentration. Because the chemical compositions and feeding values of the barley grain and RSM were very uniform throughout the experiment, only the mean values over the trials are given for barley and RSM in Table 1.

Table 1. Chemical composition and feeding values of barley, rapeseed meal and grass silages.

\begin{tabular}{|c|c|c|c|c|c|c|}
\hline & Silage trial 1 & Silage trial 2 & Silage trial 3 & $\begin{array}{c}\text { Silage mean } \\
\text { (trials } 1 \\
2,3)\end{array}$ & Barley & $\begin{array}{c}\text { Rapeseed } \\
\text { meal }\end{array}$ \\
\hline $\mathrm{N}^{\mathrm{a}}$ & 16 & 13 & 9 & 38 & 19 & 19 \\
\hline Dry matter (DM), $\mathrm{g} \mathrm{kg}^{-1}$ feed & 252 & 300 & 343 & 298 & 885 & 881 \\
\hline Organic matter (OM), $\mathrm{g} \mathrm{kg}^{-1} \mathrm{DM}$ & 937 & 936 & 918 & 930 & 975 & 927 \\
\hline Crude protein, $\mathrm{g} \mathrm{kg}^{-1} \mathrm{DM}$ & 164 & 128 & 161 & 151 & 126 & 341 \\
\hline Neutral detergent fibre (NDF), $\mathrm{g} \mathrm{kg}^{-1} \mathrm{DM}$ & 558 & 574 & 523 & 552 & 241 & 331 \\
\hline Indigestible NDF, $\mathrm{g} \mathrm{kg}^{-1} \mathrm{DM}$ & 60 & 51 & 56 & 56 & 43 & 133 \\
\hline Ether extract, $\mathrm{g} \mathrm{kg}^{-1} \mathrm{DM}$ & 39 & 35 & 38 & 37 & 16 & 44 \\
\hline Starch, $\mathrm{g} \mathrm{kg}^{-1} \mathrm{DM}$ & 14 & 7 & 8 & 10 & 524 & 30 \\
\hline Metabolizable energy, MJ kg-1 DM & 10.8 & 10.5 & 10.9 & 10.7 & 13.1 & 11.7 \\
\hline $\mathrm{AAT}^{\mathrm{c}}, \mathrm{g} \mathrm{kg}^{-1} \mathrm{DM}$ & 85 & 79 & 84 & 83 & 101 & 151 \\
\hline $\mathrm{PBV}^{\mathrm{d}}, \mathrm{g} \mathrm{kg}^{-1} \mathrm{DM}$ & 20 & -1 & 37 & 19 & -32 & 111 \\
\hline Digestible OM in DM, $\mathrm{g} \mathrm{kg}^{-1} \mathrm{DM}$ & 678 & 654 & 683 & 672 & ND ${ }^{b}$ & ND \\
\hline \multicolumn{7}{|l|}{ Fermentation quality of silage } \\
\hline $\mathrm{pH}$ & 4.06 & 4.04 & 4.56 & 4.22 & & \\
\hline Volatile fatty acids, $\mathrm{g} \mathrm{kg}^{-1} \mathrm{DM}$ & 18 & 18 & 17 & 18 & & \\
\hline Lactic + formic acid, $\mathrm{g} \mathrm{kg}^{-1} \mathrm{DM}$ & 53 & 48 & 30 & 44 & & \\
\hline Water soluble carbohydrates, $\mathrm{g} \mathrm{kg}^{-1} \mathrm{DM}$ & 47 & 67 & 101 & 72 & & \\
\hline \multicolumn{7}{|l|}{ In total $\mathrm{N}, \mathrm{g} \mathrm{kg}^{-1}$} \\
\hline $\mathrm{NH}_{4} \mathrm{~N}$ & 69 & 73 & 65 & 69 & & \\
\hline Soluble N & 534 & 540 & 511 & 528 & & \\
\hline
\end{tabular}

a Number of feed samples. Silage: values of three trials are given separately. Other feeds: only mean values over the trials are given because the chemical compositions and feeding values were very uniform throughout the experiment.

${ }^{\mathrm{b}}$ Not determined.

c Amino acids absorbed from small intestine.

d Protein balance in the rumen. 
Diet digestibility was determined for all animals when the bulls were $580 \pm 61 \mathrm{~kg}$ LW, on average. Feed and faecal samples were collected twice a day (at 7:00 a.m. and 3:00 p.m.) during the collection period (5 d) and stored frozen prior to analyses. The samples were analyzed for DM, ash, CP and NDF as described above. The diet digestibility was determined using acid-insoluble ash (AIA) as an internal marker (Van Keulen and Young 1977).

\section{Live weight, slaughter procedures and meat quality measurements}

The animals were weighed on two consecutive days at the beginning of the trials and thereafter approximately every 28 days. Before slaughter they were weighed on two consecutive days. The target for average carcass weight in the experiment was $380 \mathrm{~kg}$ for $\mathrm{Hf}$ bulls and $420 \mathrm{~kg}$ for $\mathrm{Ch}$ bulls which are nowadays the average slaughter weights for $\mathrm{Hf}$ and $\mathrm{Ch}$ bulls in Finland (Huuskonen et al. 2012). The animals were selected for slaughter based on LW and assumed dressing proportions ( 0.530 for $\mathrm{Hf}$ bulls and 560 for $\mathrm{Ch}$ bulls) which were assessed based on earlier studies (unpublished data) in Finland with beef-breed bulls. The LWG was calculated as the difference between the means of initial and final live weights divided by the number of growing days. The estimated rate of carcass gain was calculated as the difference between the final carcass weight and the carcass weight in the beginning of the experiment divided by the number of growing days. The carcass weight at the start of the experiment was assumed to be $0.50 \times$ initial LW, which was assessed based on earlier studies (unpublished data).

The animals were slaughtered in the Atria commercial slaughterhouse in Kuopio, $265 \mathrm{~km}$ from the Research Station. After slaughter the carcasses were weighed hot. The cold carcass weight was estimated as 0.98 of the hot carcass weight. Dressing proportions were calculated from the ratio of cold carcass weight to final LW. The carcasses were classified for conformation and fatness using the EUROP quality classification (EC 2006). For conformation, the development of the carcass profiles, in particular the essential parts (round, back, shoulder), was taken into consideration according to the EUROP classification (E: excellent, U: very good, R: good, O: fair, P: poor) and for fat cover degree, the amount of fat on the outside of the carcass and in the thoracic cavity was taken into account using a classification range from 1 to 5 (1: low, 2: slight, 3: average, 4: high, 5: very high). Each level of the conformation scale was subdivided into three sub-classes $\left(\mathrm{O}_{+}, \mathrm{O}, \mathrm{O}_{-}\right)$to produce a transformed scale ranging from 1 to 15 , with 15 being the best conformation.

After classification carcasses were chilled overnight below $7^{\circ} \mathrm{C}$. Day after slaughter the right side of carcasses were commercially cutted. Primal cuts were forequarter, back, side and round. The right side of each carcass was cut into valuable cuts [outside round (Musculus semitendinosus), inside round (Musculus semimembranosus), corner round (Musculus quadriceps femoris), roast beef (Musculus gluteus medius), tenderloin (Musculus psoas major), loin (Musculus longissimus lumborum) and entrecote (Musculus longissimus thoracis)], subcutaneous fat and bones as described by Manninen et al. (2011). All cuttings, subcutaneous fat and bones were weighed and their yields were expressed as percentages of the cold carcass weight ( $0.98 \times$ hot carcass weight, 50 min post mortem). Forequarter was cutted into subcutaneous fat, bones, trimmings and entrecote (Musculus longissimus thoracis between the $4^{\text {th }}$ and the $7^{\text {th }}$ rib). Back was cutted into fat, bones, trimmings and loin (Musculus longissimus lumborum between the $7^{\text {th }}$ rib and the $5^{\text {th }}$ lumbar vertebra). Loin was cutted at the level of the $1^{\text {st }}$ lumbar vertebra, and the achieved $2 \mathrm{~kg}$ loin sample between the $1^{\text {st }}$ and the $5^{\text {th }}$ lumbar vertebra was used for further analysis. The marbling score of entrecote (at the $7^{\text {th }}$ rib) and loin (at the $1^{\text {st }}$ lumbar vertebra) were evaluated by using a six-point scale $(0=$ devoid to $5=$ abundant $)$.

pH-value of the loin was measured with a Knick 651 instrument with Inlab Solid electrode (Mettler Toledo) at the level of the $1^{\text {st }}$ lumbar vertebra. Meat color of the loin was measured after a bloom time of half an hour (Warris 1996) with a Minolta Cr-200 handheld chroma meter (Minolta Camera Co., Ltd., Osaka, Japan). The chroma meter had an $8 \mathrm{~mm}$ diameter measuring area, used diffuse illumination and 0ㅇ viewing angle geometry to provide accurate readings in a wide variety of color control applications. Before measurements $\mathrm{Cr}-200$ was calibrated to a standard white plate, and CIE Standard Illuminant D65 conditions were used for the measurements. Readings were displayed in $L^{*} a * b *$ ( $L^{*}$ luminance from 0 to 100; $a *$ green to red from -60 to 60 , respectively; and b* blue to yellow from -60 to 60 , respectively). Each sample was measured three times and a mean value was calculated.

During cutting, a $2 \mathrm{~kg}$ loin sample was taken and vacuum packed. These samples were sent to the Finnish Meat Research Institute (LTK) for further analyses. Total ageing time of samples was 8 days at $4{ }^{\circ} \mathrm{C}$. Thereafter samples were analysed for drip loss, moisture, protein and fat concentrations, Warner-Bratzler shear force and for tenderness, juiciness and beef flavour (sensory analysis). Drip loss was determined by the amount of water loss from the $2 \mathrm{~kg}$ loin sample after ageing. Moisture, protein and fat concentrations were determined as described by Huuskonen et al. (2010). For shear force measurements, loin samples were heated in a water bath at $85^{\circ} \mathrm{C}$ 
until the core temperature of the meat was $70^{\circ} \mathrm{C}$. After chilling for 24 hours $\left(4^{\circ} \mathrm{C}\right)$, loin samples about $6 \mathrm{~cm}$ long (parallel to the myofibres), $1 \mathrm{~cm}$ high and $1 \mathrm{~cm}$ wide (square probe of $1 \mathrm{~cm} \times 1 \mathrm{~cm}$ surface area) were placed in a Warner-Bratzler shear blade to be sheared perpendicular to the longitudinal axis of the muscle fibres in an Instron testing machine. The maximum force was recorded and results were expressed as kg $\left(\mathrm{cm}^{-2}\right)^{-1}$ (Honkavaara et al. 2003) because the sheared meat sample had a height of $1.0 \mathrm{~cm}$ and a width of $1.0 \mathrm{~cm}$ and a length of $6.0 \mathrm{~cm}$. Thus the shear force is expressed as kg per sheared surface area of $1.0 \mathrm{~cm}^{2}$.

For the sensory analysis, surface fat was removed and trimmed loin was cut into four slices with thickness of 1.5 $\mathrm{cm}$. After that these four samples were heated simultaneously up to internal temperature of $68^{\circ} \mathrm{C}$ in a rolling grill (Palux Rotimat, Germany). Heated samples were served immediately in a sensory panel room with white lightning and temperature of $24^{\circ} \mathrm{C}$. Six trained sensory panelists evaluated the samples for tenderness, juiciness and beef flavour. These traits were scored on a seven-point scale ( 1 = very tough/very dry/very non beef like,..., $7=$ very/tender/very juicy/very beef like).

Fatty acids were extracted from loin samples according to a slightly modified AOAC standard method (AOAC 2002) and methylated to corresponding fatty acid methyl esters (FAMEs) in hexane with $2 \mathrm{M}$ sodium hydroxide and $1 \mathrm{M}$ hydrochloride acid in methanol. FAMEs were analyzed using a gas chromatograph (Agilent 6850 Series) equipped with flame ionization detector by a previously published method (Jaakkola et al. 2012) with modified temperature program: the temperature was increased $25^{\circ} \mathrm{C} \mathrm{min}-1$ from $35^{\circ} \mathrm{C}$ to $190^{\circ} \mathrm{C}$, and then by $3^{\circ} \mathrm{C} \mathrm{min}^{-1}$ to $205^{\circ} \mathrm{C}$ and then to $220^{\circ} \mathrm{C}$ with $8^{\circ} \mathrm{C} \mathrm{min}^{-1}$, and finally held there for $22 \mathrm{~min}$. FAMEs were identified by comparing samples with fatty acid standards GLC 461, UC-60M, U-48M, U-69M, U-99M, U-101M and U-84M (Nu-chek Prep Inc., Elysian, MN, USA). Methyl stearate (Sigma-Aldrich) was used for quantification purposes.

\section{Statistical methods}

The results were analysed across all three trials (results of meat quality and valuable cuts across two trials) and are shown as least squares means. The normality of analysed variables was checked using graphical methods: boxplot and scatter plot of residuals and fitted values. The data were subjected to analysis of variance using the SAS MIXED procedure (version 9.1, SAS Institute Inc., Cary, NC). The statistical model used was

$y_{i j k l m}=\mu+\delta_{1}+\alpha_{i}+\beta_{j}+\gamma_{k}+(\alpha \times \beta)_{i j}+(\alpha \times \gamma)_{i k}+(\beta \times \gamma)_{j k}+(\alpha \times \beta \times \gamma)_{i j k}+(\delta \times \alpha \times \beta \times \gamma)_{i j k}+e_{i j k l m}$

where $\mu$ is intercept and $e_{i j k l m}$ is the random error term associated with $m^{\text {th }}$ animal. $\alpha_{i}, \beta_{j}$ and $\gamma_{k}$ are the fixed effects of $\mathrm{i}^{\text {th }}$ breed $(\mathrm{Hf}, \mathrm{Ch})$, $\mathrm{j}^{\text {th }}$ concentrate level $(200,500)$ and $\mathrm{k}^{\text {th }}$ RSM supplementation (RSM-, RSM+), respectively. $\delta_{1}$ is random effect of $I^{\text {th }}$ trial $(I=1,2,3) .(\delta \times \alpha \times \beta \times \gamma)_{\text {lijk }}$ is random effect of trial-by-treatment which is used as an error term when differences between treatments (=breed, concentrate level, RSM supplementation) were tested.

\section{Results}

The average chemical compositions of the TMR used are presented in Table 2. Because of the higher energy and AAT contents of the concentrate, increasing the concentrate proportion increased the calculated energy and AAT values of the rations. Increasing the proportion of the concentrate also increased the starch content, but decreased the NDF content of the rations. The CP content of the $L$ and $M$ rations increased 8 and $12 \%$ with RSM supplementation, respectively (Table 2 ).

\section{Diet digestibility, feed intake and growth performance}

Significant, but numerically small, breed $\times$ concentrate level $\times$ RSM supplementation three-way interactions were observed for the DM, OM and NDF digestibilities (Table 3). Other interactions for digestibility variables between breed, concentrate level and RSM supplementation were not observed. Breed had no effects $(p>0.05)$ on the diet digestibility coefficients (Table 3 ). Increasing the concentrate proportion led to improved DM $(p<0.001), 0 M$ $(p<0.001)$ and CP $(p<0.01)$ apparent digestibilities. The digestibility of NDF decreased $3 \%$ with increasing concentrate proportion $(p<0.001)$. Rapeseed meal supplementation had no effect on the DM, OM and NDF digestibilities, but the CP digestibility was $7 \%$ higher for the RSM+ diets than for the RSM-diets $(p<0.001)$. 
Table 2. Chemical compositions and nutritional values of total mixed rations used (mean values of three trials).

\begin{tabular}{|c|c|c|c|c|}
\hline Concentrate proportion, $\mathrm{g} \mathrm{kg}^{-1}$ dry matter (DM) ${ }^{\text {a }}$ & L (200) & L (200) & $M(500)$ & $M(500)$ \\
\hline Rapeseed meal supplementation & - & + & - & + \\
\hline DM, $\mathrm{g} \mathrm{kg}^{-1}$ feed & 344 & 344 & 446 & 446 \\
\hline Organic matter, $\mathrm{g} \mathrm{kg}^{-1} \mathrm{DM}$ & 939 & 937 & 953 & 949 \\
\hline Crude protein, $\mathrm{g} \mathrm{kg}^{-1} \mathrm{DM}$ & 146 & 157 & 139 & 155 \\
\hline Neutral detergent fibre (NDF), $\mathrm{g} \mathrm{kg}^{-1} \mathrm{DM}$ & 490 & 494 & 397 & 403 \\
\hline Ether extract, $\mathrm{g} \mathrm{kg}^{-1} \mathrm{DM}$ & 33 & 34 & 27 & 28 \\
\hline Starch, $\mathrm{g} \mathrm{kg}^{-1} \mathrm{DM}$ & 113 & 88 & 267 & 230 \\
\hline Metabolizable energy, $\mathrm{MJ} \mathrm{kg}^{-1} \mathrm{DM}$ & 11.2 & 11.1 & 11.9 & 11.8 \\
\hline Amino acids absorbed from small intestine, $\mathrm{g} \mathrm{kg}^{-1} \mathrm{DM}$ & 87 & 89 & 92 & 96 \\
\hline Protein balance in the rumen, $\mathrm{g} \mathrm{kg}^{-1} \mathrm{DM}$ & 9 & 18 & -7 & 7 \\
\hline
\end{tabular}

${ }^{\mathrm{a}} \mathrm{L}=$ low concentrate proportion (200 $\left.\mathrm{g} \mathrm{kg}^{-1} \mathrm{DM}\right) ; \mathrm{M}=$ medium concentrate proportion (500 $\left.\mathrm{g} \mathrm{kg}^{-1} \mathrm{DM}\right)$.

There were no differences in average DM, energy and CP intakes between $\mathrm{Hf}$ and $\mathrm{Ch}$ bulls (Table 3 ). Instead, increasing the level of concentrate led to higher DM $(p<0.001)$, energy $(p<0.001)$ and CP $(p<0.01)$ intakes by the bulls whereas the supply of NDF decreased $(p<0.001)$ with increasing concentrate level. There were also interactions $(p<0.05)$ between the breed and the concentrate level for DM, energy and CP intakes. Intake increased more with the $\mathrm{Ch}$ bulls than with the $\mathrm{Hf}$ bulls as a consequence of increased concentrate level. The average supply of CP $(p<0.001)$, AAT $(p<0.05)$ and PBV $(p<0.001)$ were higher when RSM was included in the diet, but RSM supplementation had no effect on the average DM or energy intake.

There were no significant interactions for live weight or gain variables between breed, concentrate level and RSM supplementation (Table 3). The mean final LW of the $\mathrm{Hf}$ and Ch bulls were 726 and $754 \mathrm{~kg}$, respectively. The live weight gain and carcass gain of the Ch bulls were 10 and $22 \%$ higher than those of the Hf bulls, respectively $(p<0.001)$. Increasing the proportion of concentrate led to an improvement of daily LWG and carcass gain of the bulls $(p<0.001)$. The RSM supplementation had no effect on growth performance, but LWG and carcass gain of the bulls tended to be $5 \%$ lower on RSM- diets than on RSM+ diets $(p=0.08)$.

There were no interactions for feed conversion variables between breed, concentrate level and RSM supplementation. Feed conversion ( $\mathrm{kg} \mathrm{DM} \mathrm{kg}^{-1}$ carcass gain) and energy conversion rates ( $\mathrm{MJ} \mathrm{ME} \mathrm{kg} \mathrm{carcass}^{-1}$ gain) improved 14 and $7 \%$, respectively, with increasing concentrate proportion ( $p<0.001$ and $p<0.01$, respectively). Both feed and energy conversion rates were poorer with $\mathrm{Hf}$ than with Ch bulls (13.5 vs. $11.3 \mathrm{~kg} \mathrm{DM} \mathrm{kg}^{-1}$ carcass gain and 155 vs. $131 \mathrm{MJ} \mathrm{kg}^{-1}$ carcass gain, respectively, $\left.p<0.001\right)$. The RSM supplementation had no effect on feed or energy conversion, but both variables tended to be $5 \%$ poorer on RSM-diets than on $\mathrm{RSM}+$ diets $(p<0.1)$.

\section{Carcass characteristics and valuable cuts}

There were no interactions for carcass weight or dressing proportion between breed, concentrate level and RSM supplementation. The mean carcass weights of the $\mathrm{Hf}$ and $\mathrm{Ch}$ bulls were 386 and $426 \mathrm{~kg}$, respectively, and close to the pre-planned carcass weight (Table 3). The carcass weight of the M bulls was $5 \%$ higher than that of the $L$ bulls (396 vs. $416 \mathrm{~kg}, p<0.01$ ). The RSM supplementation had no effect on carcass weight. The dressing proportion of the Ch bulls was $6 \%$ higher than that of the $\mathrm{Hf}$ bulls ( $531 \mathrm{vs} .562 \mathrm{~g} \mathrm{~kg}^{-1}, p<0.001$ ). The dressing proportion of the $\mathrm{M}$ bulls was $1 \%$ higher than that of the $\mathrm{L}$ bulls ( $543 \mathrm{vs} .550 \mathrm{~g} \mathrm{~kg}^{-1}, p<0.05$ ), but the RSM supplementation had no effect on dressing proportion.

The carcass conformation score of the Ch bulls was $32 \%$ higher than that of the Hf bulls $(6.5$ vs. $8.6, p<0.001)$ and the conformation of the $\mathrm{M}$ bulls was $17 \%$ higher than that of the $\mathrm{L}$ bulls (6.9 vs. 8.1, $p<0.001)$. There was also an interaction $(p<0.01)$ between the breed and the concentrate level for carcass conformation. The conformation score of the Ch bulls improved more than that of the $\mathrm{Hf}$ bulls as a consequence of increased concentrate level (Table 3). The RSM supplementation had no effect on carcass conformation score. Carcass fat score of the Hf bulls was $55 \%$ higher than that of the Ch bulls ( 4.5 vs. $2.9, p<0.001$ ). The concentrate level had no effect on carcass fat score, but it tended to be $7 \%$ higher on $M$ diets than on $L$ diets ( 3.8 vs. 3.6, $p=0.06$ ). The RSM supplementation had no effect on carcass fat score, and there were no interactions for carcass fat score between breed, concentrate level and RSM supplementation (Table 3). 


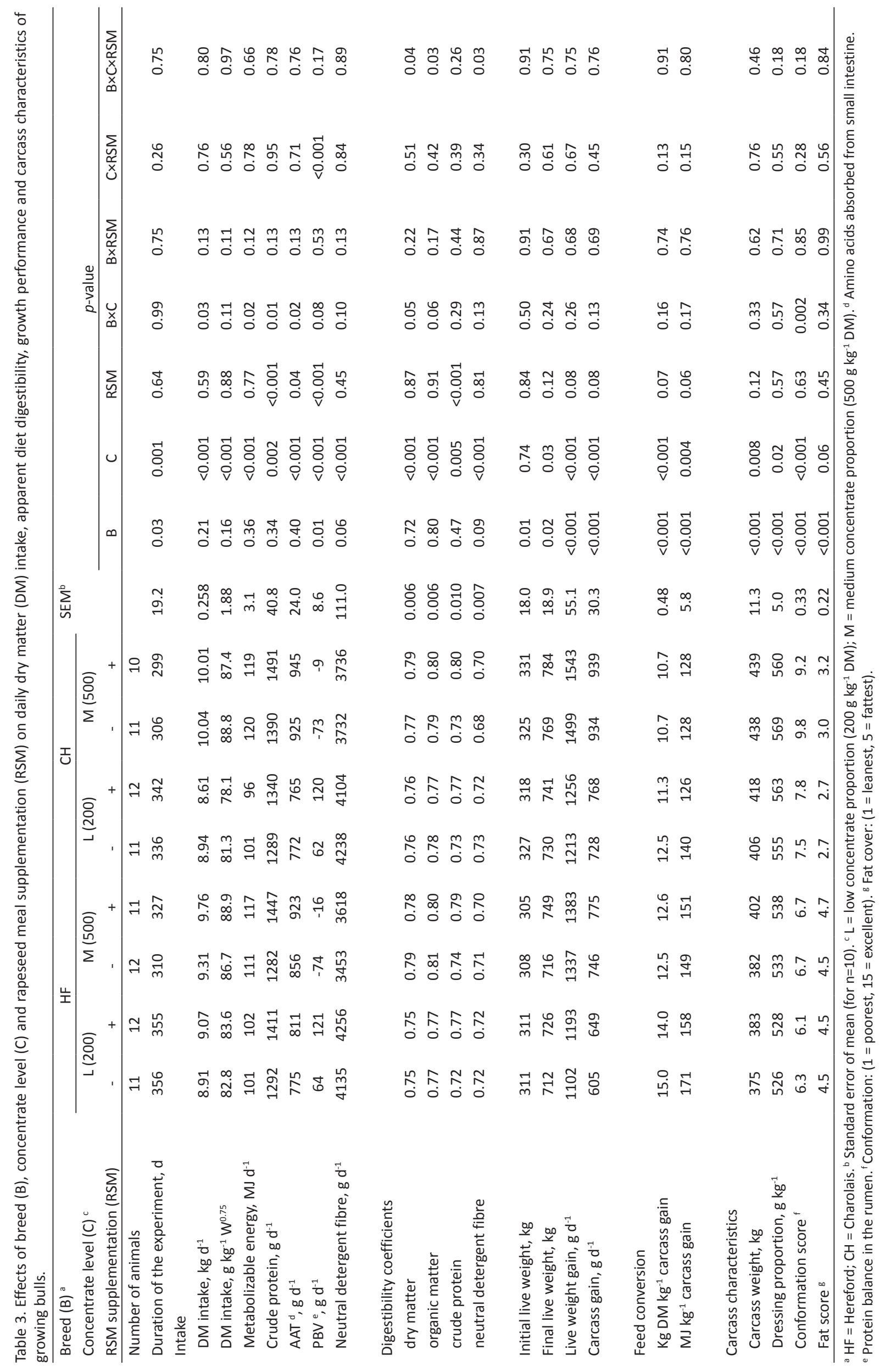




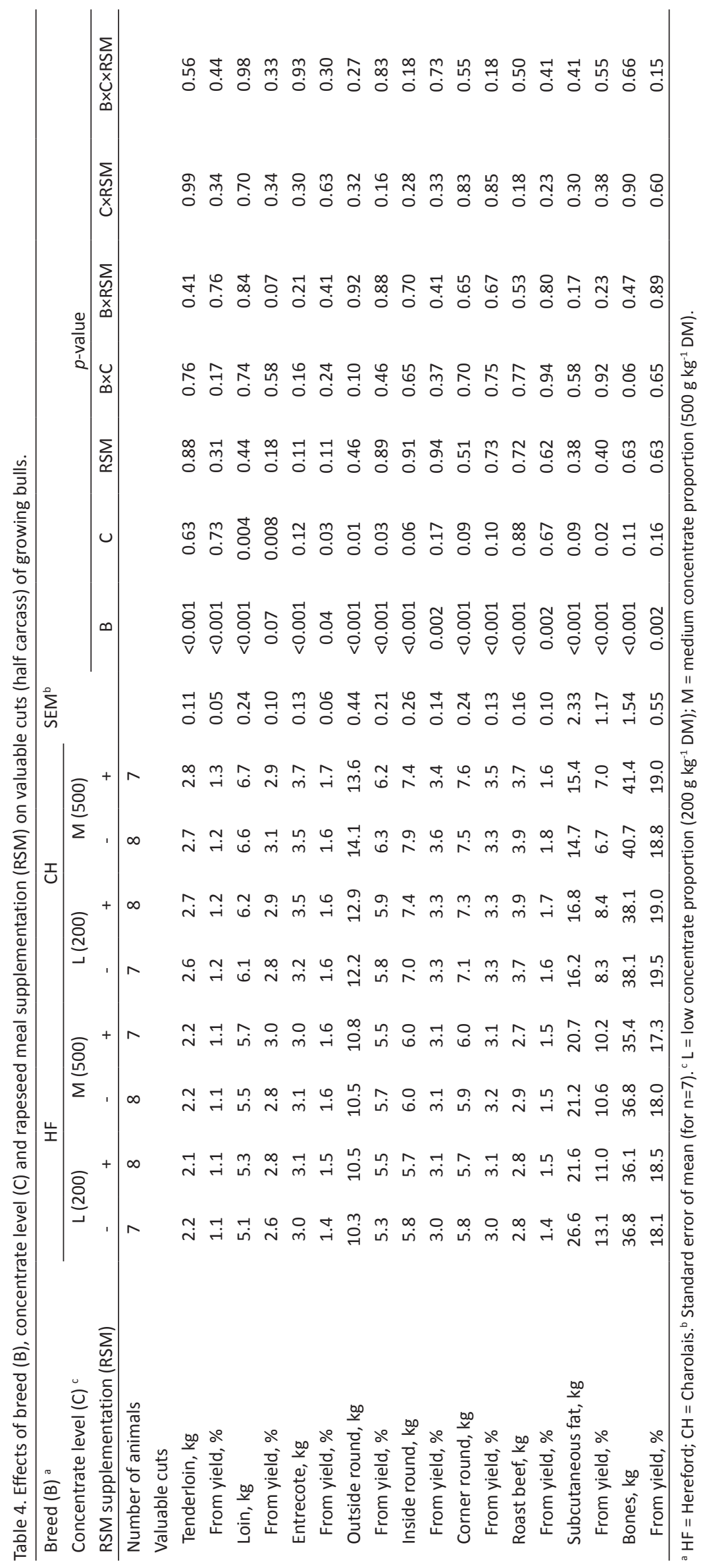


There were no significant interactions for carcass cuts between breed, concentrate level and RSM supplementation (Table 4). Breed had a clear effect on the amount ( $\mathrm{kg}$ ) and yield (\%) of valuable cuts. The yields of tenderloin $(p<0.001)$, loin $(p=0.07)$ and entrecote $(p<0.05)$ were 13,4 and $5 \%$ higher with $\mathrm{Ch}$ than with Hf bulls, respectively. In addition, the yields of outside round $(p<0.001)$, inside round $(p<0.01)$, corner round $(p<0.001)$ and roast beef $(p<0.01)$ were $9,10,10$ and $14 \%$ higher with Ch than with $\mathrm{Hf}$ bulls, respectively. The yield of subcutaneous fat was $49 \%$ higher $(p<0.001)$ from the carcasses of the $\mathrm{Hf}$ bulls than those of the Ch bulls. On the contrary, the yield of bones was $6 \%$ higher $(p<0.01)$ from the carcasses of the $\mathrm{Ch}$ bulls than those of the $\mathrm{Hf}$ bulls. Concentrate level affected the yields of loin, entrecote, outside round and subcutaneous fat (Table 4). The yields of loin $(p<0.01)$, entrecote $(p<0.05)$ and outside round $(p<0.05)$ were 6,5 and $5 \%$ higher with M bulls than with L bulls, respectively. The yield of subcutaneous fat was $18 \%$ higher $(p<0.05)$ from the carcasses of the $L$ bulls than from those of the $M$ bulls. The RSM supplementation had no effect on the amount and yield of valuable cuts.

\section{Meat evaluation}

The treatments had no effects on the $\mathrm{pH}$ of the carcasses, but significant breed $\times$ concentrate level $\times$ RSM supplementation three-way interaction was observed (Table 5). The loin sample of the Ch bulls had higher moisture (739 vs. $\left.726 \mathrm{~g} \mathrm{~kg}^{-1}, p<0.001\right)$ and protein ( $\left.213 \mathrm{vs.} 210 \mathrm{~g} \mathrm{~kg}^{-1}, p<0.05\right)$ and lower fat ( $\left.35 \mathrm{vs.} 51 \mathrm{~g} \mathrm{~kg}^{-1}, p<0.001\right)$ contents than that of the $\mathrm{Hf}$ bulls. Concentrate level and RSM supplementation had no effects on the chemical composition of loin, and there were no significant interactions between breed, concentrate level and RSM supplementation. Breed affected the marbling score of loin and entrecote (Table 5). The loin $(p<0.001)$ and entrecote $(p<0.01)$ of the $\mathrm{Hf}$ bulls had 39 and $44 \%$ higher marbling scores than those of the Ch bulls, respectively. Concentrate level and RSM supplementation had no effects on the marbling score of the loin or entrecote. Interactions for marbling scores between breed, concentrate level and RSM supplementation were not observed.

There were no interactions for shear force value, drip loss, colour or sensory characteristics between breed, concentrate level and RSM supplementation (Table 5). The treatments had no effects on the drip loss, but the shear force value of the $\mathrm{Ch}$ bulls was $13 \%$ higher than that of the $\mathrm{Hf}$ bulls ( $\left.9.9 \mathrm{vs} .8 .8 \mathrm{~kg} \mathrm{~cm}^{-1}, p<0.05\right)$. Concentrate level and RSM supplementation had no effects on the shear force value. The muscle lightness ( $L$ value) of the Ch bulls was $8 \%$ higher than that of the $\mathrm{Hf}$ bulls $(p<0.001)$, but there were not differences in redness ( $a$ value) or yellowness ( $b$ value) between breeds. In addition, the muscle lightness was $3 \%$ higher with $\mathrm{M}$ bulls than with $\mathrm{L}$ bulls, but concentrate level did not affect the muscle redness or yellowness. The RSM supplementation had no effects on any of the measured meat colour parameters. Treatments had no effects on the sensory characteristics (tenderness, juiciness, beef flavour) of the loin, but there was a tendency $(p=0.08)$ for tenderness to be $6 \%$ better for the meat of the $\mathrm{Hf}$ bulls than that of the Ch bulls.

The $n-6 / n-3$ fatty acid ratio of the longissimus muscle (LM) of the Ch bulls was $20 \%$ higher than the corresponding value for the $\mathrm{Hf}$ bulls $(\mathrm{p}<0.01)$ (Table 6$)$. In addition, the LM of the Ch bulls contained a higher proportion of polyunsaturated fatty acids (PUFA) compared to that of the $\mathrm{Hf}$ bulls $(\mathrm{p}<0.001)$. On the contrary, the LM of the $\mathrm{Hf}$ bulls contained a higher proportion of monounsaturated fatty acids (MUFA) compared to that of the Ch bulls $(p<0.01)$. Breed had no effect on the proportion of saturated fatty acids (SFA). The LM of the Hf bulls had a higher proportion of 10:0 ( $p<0.05), 18: 1$ cis-9 $(p<0.001)$ and 20:1 cis-11 ( $p<0.05)$ fatty acids compared to that of the Ch bulls. On the contrary, the LM of the Ch bulls contained a higher proportion of 15:0 ( $p<0.01), 16: 0(p<0.05), 16: 1$ cis-9 ( $p<0.001), 18: 1$ cis-11 ( $p<0.001), 18: 2$ cis-9,cis-12 ( $p<0.001), 18: 3$ cis-9,cis-12,cis-15 ( $p<0.001), 18: 3$ cis-6, cis9 ,cis-12 $(p<0.001)$ and $20: 3$ cis-8, cis-11, cis-14 ( $p<0.01)$ fatty acids compared to that of the Hf bulls.

The $n-6 / n-3$ fatty acid ratio of the LM increased $59 \%$ with higher concentrate level $(p<0.001)$ and the LM of the M bulls also tended $(p=0.05)$ to contain a $5 \%$ higher proportion of MUFA compared to that of the $L$ bulls (Table 6). On the contrary, the LM of the L bulls tended $(p=0.06)$ to have a $4 \%$ higher proportion of SFA compared to that of the $\mathrm{M}$ bulls. Concentrate level had no effect on the proportion of PUFA. The increasing concentrate level decreased the relative proportion of 15:0 ( $p<0.001), 17: 0(p<0.001), 18: 1$ cis-11 $(p<0.05)$ and 18:3 cis-9,cis-12,cis-15 $(p<0.001)$ fatty acids of the LM and increased the relative proportion of 18:1 cis-9 $(p<0.05)$ and $18: 2$ cis-9,cis-12 $(p<0.01)$ fatty acids of the LM. In addition, the LM of the M bulls tended $(p=0.09)$ to have a higher proportion of 10:0 fatty acid compared to that of the $L$ bulls (Table 6 ). 


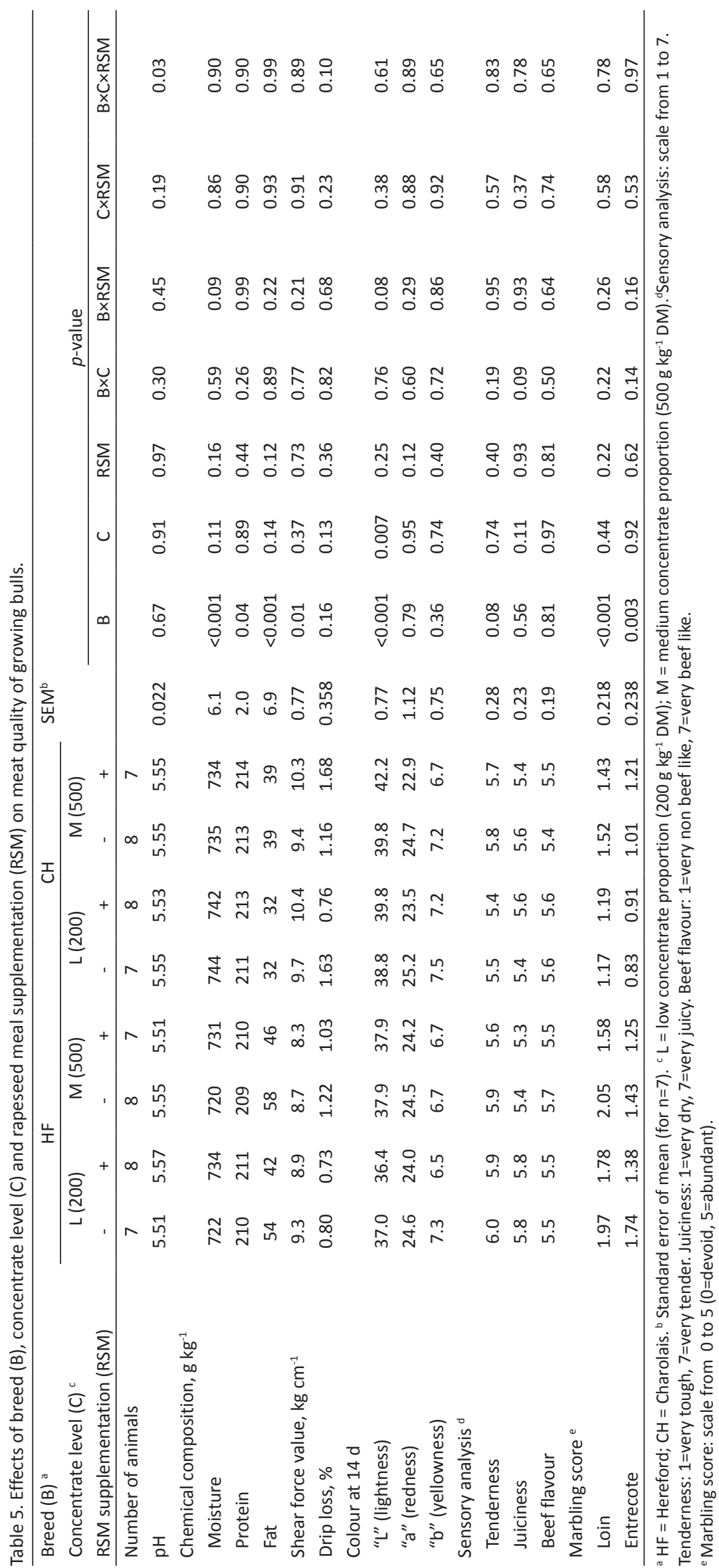




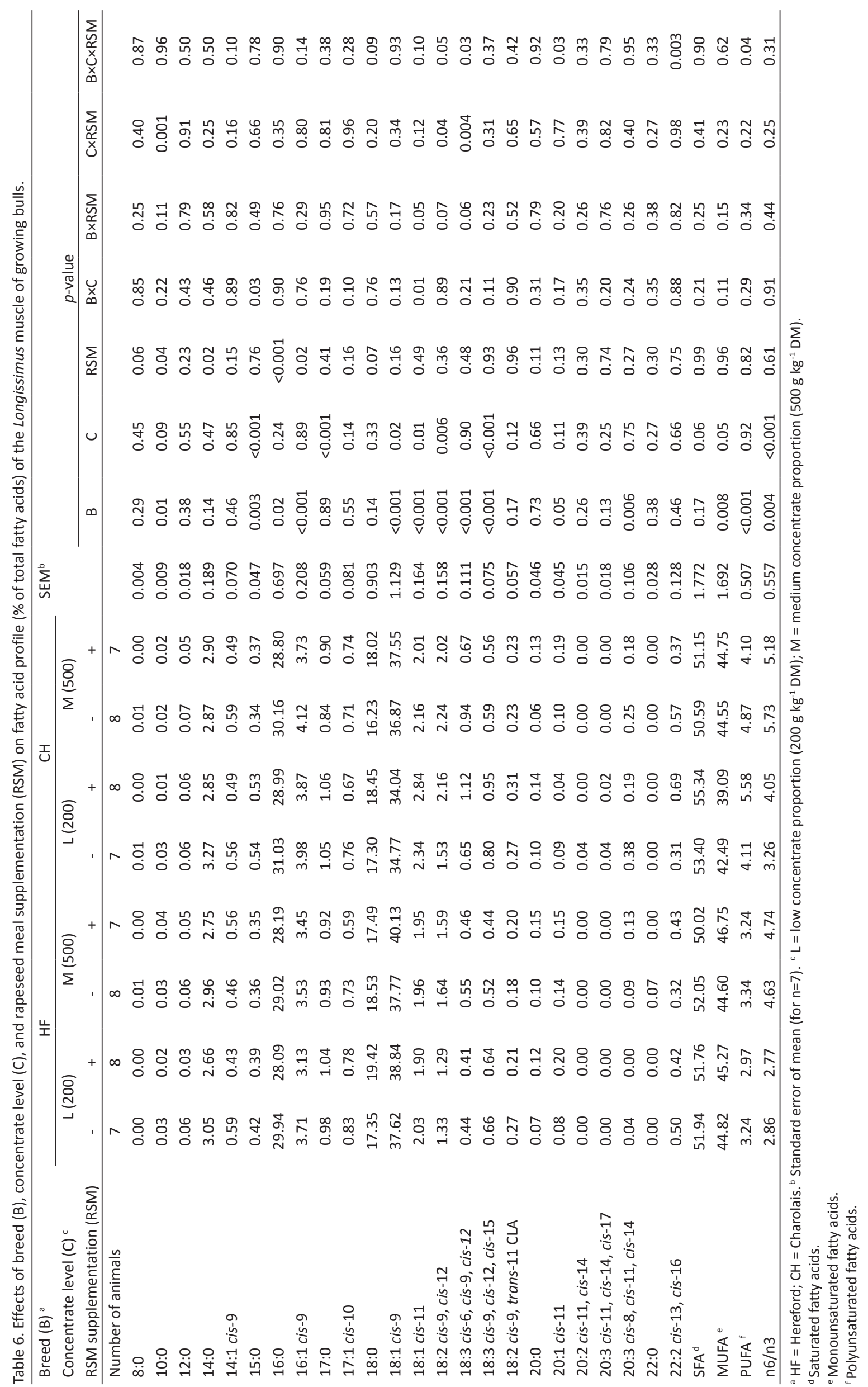


There were no effects of RSM supplementation on the $n-6 / n-3$ fatty acid ratio of the LM or on the proportion of SFA, MUFA or PUFA. However, RSM supplementation decreased the relative proportion of 10:0 $(p<0.05), 14: 0$ $(p<0.05), 16: 0(p<0.001)$ and $16: 1$ cis-9 $(p<0.05)$ fatty acids of the LM. There were also interactions $(p<0.05)$ between breed and concentrate level for the relative proportion of 15:0 and 18:1 cis-11 fatty acids, and between the breed and RSM supplementation for the relative proportion of 18:1 cis-11 fatty acid (Table 6). In addition, there were interactions between concentrate level and RSM supplementation for the relative proportion of 10:0, 18:2 cis-9,cis-12 and 18:3 cis-6,cis-9,cis-12 fatty acids. Significant breed $\times$ concentrate level $\times$ RSM supplementation three-way interactions were observed for the relative proportion of 18:2 cis-9,cis-12, 18:3 cis-6,cis-9,cis-12, 20:1 cis-11 and 22:2 cis-13,cis-16 fatty acids and for the proportion of PUFA (Table 6).

\section{Discussion}

\section{Animal performance}

The increased apparent digestibility of DM (DMD) and OM (OMD) of grass silage-based diets due to increasing concentrate feed level has been well documented (Huuskonen et al. 2007, Keady et al. 2007, 2008). The substitution of silage with barley improved the digestibility, because the digestibility of barley is generally higher than that of grass silage (MTT 2012). The reduction in fibre digestibility due to increased concentrate level has been reported previously Steen et al. (2002), Huuskonen et al. (2007) and Keady et al. (2007, 2008). The negative associative effect is attributed to a depression in fibre digestibility in the rumen and in the total digestive tract from inclusion of rapidly fermentable carbohydrates such as barley-based (starch) concentrate (Huhtanen and Jaakkola 1993) and sucrose (Khalili and Huhtanen 1991) in grass silage-based diets. In accordance with Huuskonen et al. $(2007,2008 \mathrm{~b})$ and Huuskonen $(2009 \mathrm{~b})$, the apparent CP digestibility increased with protein supplementation. Some of the increased apparent digestibility of the CP in the RSM supplemented diets may have reflected the better digestibility of RSM protein. Most of this increase was, probably, only apparent, related to the decreased proportion of faecal metabolic nitrogen recovered in faeces when the CP content increased (Minson 1982). Similarly, as reported by Huuskonen et al. (2007) and Huuskonen (2009b), RSM supplementation had no effect on diet apparent DMD or OMD when barley grain was partly replaced by RSM. Most of the experiments in which protein supplementation resulted in positive effects on fibre digestion, have been conducted with poor quality roughages (Huuskonen 2009a).

The concentrate proportion had a positive effect on the total DMI which is in accordance with results of beef steers in grass silage-based diets (Caplis et al. 2005, Keane et al. 2006). The substitution rate (SR, decrease in silage DMI per kg increase of concentrate DMI) in the current experiment was 0.81 and 0.60 for $\mathrm{Hf}$ and Ch bulls, respectively. These results are in line with grass silage-based feedings reported by Keane (2010) with crossbred steers (SR 0.82), Manninen et al. (2010) with Hf bulls (SR 0.71 and 0.53 for farm-made concentrate mixture and commercial compound, respectively) and Randby et al. (2010) with dairy bulls (SR 0.75). McNamee et al. (2001) reported that concentrate feed level and silage feed value are major factors affecting the concentrate substitution rate. For example, Keady and Kilpatrick (2006) (beef-breed bulls) and Steen et al. (2002) (beef-breed steers), using high-feed value grass silages, reported substitution rates of 0.91 and up to 1.00 , respectively. The concentrate protein concentration did not affect DMI, which was consistent with the results observed with heavy dairy bulls (Huuskonen et al. 2007, Huuskonen 2009b), finishing Hereford bulls (Manninen et al. 2011) or suckled continental-cross bulls (Drennan et al. 1994) with grass silage-based diets.

The higher growth capacity of the Charolais breed compared to the Hereford breed has been demonstrated in numerous studies (e.g. Gregory et al. 1994, Aass and Vangen 1998, Bartoň et al. 2006). In the present experiment, the observed increase in LWG was 75 and $91 \mathrm{~g} \mathrm{~d}^{-1}$ per $1 \mathrm{~kg}$ increase in concentrate DMI for Hf and Ch bulls, respectively. These outcomes are consistent with grass silage feeding experiments reported by Martinsson (1990) with dairy bulls ( $84 \mathrm{~g} \mathrm{~d}^{-1}$ ) and Manninen et al. (2010) with $\mathrm{Hf}$ bulls ( 85 and $90 \mathrm{~g} \mathrm{~d}^{-1}$, for farm-made concentrate mixture and commercial compound, respectively), but sometimes responses have been even smaller (dairy bulls, $27 \mathrm{~g} \mathrm{~d}^{-1}$ ) (Huuskonen et al. 2007). The improved growth rate in the present experiment was probably due to improved diet digestibility and increased DM and energy intakes with increasing concentrate proportion.

In the present experiment, the growth rate of the bulls tended to be slightly lower on RSM- diets than on RSM+ diets, which disagrees with the findings by Huuskonen et al. (2007, 2008b) and Huuskonen (2009b, 2011) with dairy bulls. The observed response in LWG due to RSM supplementation was slightly higher with lower concentrate proportion (67 vs. $45 \mathrm{~g} \mathrm{~d}^{-1}$ for $\mathrm{L}$ and $\mathrm{M}$ feedings, respectively). This is in line with Huuskonen (2009a) who concluded that the responses to protein supplements seem to be related also to the level of concentrate supplement, greater effects being observed with small amounts of concentrates. Hagemeister et al. (1980) reported a 
tendency towards lower rumen protein synthesis with rations containing very low (0-20\%) or very high (70-100 \%) proportions of concentrate, and according to Aronen (1992), a medium level of concentrates together with well preserved grass silage may sustain efficient microbial protein production. Therefore, it is likely that a greater response to protein supplementation is to be expected when small rather than large amounts of concentrates are fed to growing cattle on grass silage-based feeding.

In general, the responses to protein supplements are also related to the quality of grass silage used. There is evidence that growing cattle are likely to respond to supplementary protein in barley-based concentrates when the digestibility of the grass silage is moderate to low (Huuskonen 2009a). In addition, results with grass silage are dependent on the quality of silage that may vary considerably with the ensiling technique. With poorly preserved silage the response in animal performance to protein supplementation is greater than with well-preserved silage (Hussein and Jordan 1991). There are also differences between extensively and restrictively fermented silages, which both may be well-preserved. Jaakkola et al. (1990) reported that the gain response of growing cattle to fishmeal was greater when enzyme solution (cellulose-glucose oxidase) was used as a silage additive instead of formic acid. Furthermore, Jaakkola et al. (2006) observed that restriction of silage fermentation by formic acid is positively related to the synthesis of microbial protein in the rumen. In the present experiment the fermentation quality of the silages was good and the silages were restrictively fermented with high residual WSC concentration and low lactic acid concentration. Possibly, the responses to protein supplementation may have been greater with untreated and/or poorly preserved silage.

\section{Carcass characteristics and valuable cuts}

The superiority of the Ch bulls for the dressing proportion and carcass conformation corresponded to the results reported by Polách et al. (2004) and Bartoň et al. (2006). The lower dressing proportion and conformation score of the $\mathrm{Hf}$ bulls in the present experiment can also be explained partly by their lower average slaughter weight compared to Ch bulls because it is established that these traits increased with increasing slaughter weight (Kempster et al. 1988). However, according to Lawrence et al. (2012) the body composition of beef breeds is not only dependent on carcass weight. For example, when early maturing $\mathrm{Hf}$ and late maturing Blonde d'Aquitaine breeds were compared, the relative fatness of both breeds remained quite similar at different weights. Both breeds increased in fatness as the carcass weight increased but the differential remained quite constant (Lawrence et al. 2012). The different breed bulls are in different stages of their growth path from the beginning of the growing till the end of finishing. The mature weight of the $\mathrm{Ch}$ bulls is larger than the $\mathrm{Hf}$ bulls but also the tissue composition is different (Alberti et al. 2008). In this regard the Ch bulls will not reach the similar body composition (fat vs. lean) as adult animals such as the $\mathrm{Hf}$ bulls. It is justifiable to suppose that the apparently higher carcass efficiency of the Ch bulls compared to the Hf bulls observed in the present experiment was real, and the differences were not only an effect of differences in biological maturity.

The increasing effect of concentrate level on dressing proportion agrees with previous reports (Caplis et al. 2005, Keane et al. 2006). In the present experiment, increasing concentrate proportion also improved the carcass conformation, consistent with Keane and Fallon (2001) and Caplis et al. (2005), but contrary to Huuskonen et al. (2007), Manninen et al. (2010) and Randby et al. (2010). Increasing the concentrate level has usually increased the carcass fat score (Patterson et al. 2000, Keane et al. 2006) as in the present experiment. Also higher slaughter weights with increasing concentrate level probably explained the increased fat score, because measures of fatness generally increase with higher carcass weight (Keane and Allen 1998). In accordance with many earlier studies (Huuskonen et al. 2007, 2008b, Manninen et al. 2010, Huuskonen 2009, 2011), there were no effects of protein supplementation on the dressing proportion, carcass conformation score or carcass fat score.

Manninen et al. (2011) reported a similar carcass share of valuable cuts in Hf bulls to those obtained in the present paper. A number of studies have confirmed a higher share of the most valuable cuts in the carcasses of $\mathrm{Ch}$ bulls compared to Hf bulls (e.g. Bartoň et al. 2006, Kaminiecki et al. 2009). Also Kempster et al. (1982) reported a lower saleable meat proportion from carcasses of Hf-sired steers than from carcasses of Ch steers compared at 16 months of age. Similarly to our findings, Bartoň et al. (2006) observed that Hf bulls had a lower percentage of bones compared to Ch bulls. The effects of concentrate proportions on the yields of valuable cuts were quite small and there were only few differences between the different concentrate levels which agree with the findings by Patterson et al. (2000), Caplis et al. (2005) and Keane et al. (2006). Patterson et al. (2000) speculated that the absence of any effect of concentrate proportion on the content of saleable meat in the carcass was considered to reflect the high growth potential of the animals (Blonde d'Aquitaine and Ch bulls). Caplis et al. (2005) observed that bone proportion decreased in growing beef steers with increasing concentrate level which disagrees with 
our observation. In accordance with the present study, Manninen et al. (2011) reported that the protein supplementation had no effect on the amount and yield of valuable cuts in beef bulls.

\section{Meat quality measurements}

The meat colour differences between the breeds corresponded to those reported by Aass and Vangen (1998) who reported meat from $\mathrm{Ch}$ to be lighter than meat from $\mathrm{Hf}$. Some studies associated increased lightness with reduced pigment content in the meat of $\mathrm{Ch}$, which suggests the presence of breed differences in relative muscle fibre proportion. Such physiological changes may be related to high genetic growth capacity and increased muscularity (Ashmore and Vigneron 1988). In accordance with Bureš et al. (2006), the meat samples from Hf bulls had higher DM and lipid contents and a lower protein content than the samples from Ch bulls. These results indicate that the increase in lipid concentrations was associated with the increased DM content and the decreased protein content, which is in accordance with the findings by Van Koevering et al. (1995). Similarly to the present results, greater intramuscular fat deposition and lower moisture in $\mathrm{Hf}$ steers compared with Ch steers were reported by Gregory et al. (1994).

In agreement with our findings, Bureš et al. (2006) reported no significant effects on sensory characteristics (juiciness, beef flavour) between $\mathrm{Hf}$ and $\mathrm{Ch}$ bulls. In our study, however, there was a tendency for the tenderness to be $6 \%$ better in the meat of the $\mathrm{Hf}$ bulls than that of the Ch bulls. Similarly, poorer tenderness was achieved by large, late maturing Ch steers than by small, early maturing, and fatter Aberdeen Angus steers (Sinclair et al. 2001). The superiority of $\mathrm{Hf}$ in tenderness and shear force has been related to a higher marbling level. Several authors (e.g. Gregory et al. 1994, Wheeler et al. 1996) have reported a favourable relationship between intramuscular fat content and shear force/tenderness scores. Aass and Vangen (1998) concluded that a superiority of Aberdeen Angus in intramuscular fat content of the meat has been demonstrated in many studies, and $\mathrm{Hf}$ was generally ranked similar or somewhat lower than Angus for this trait, while Ch had the lowest degree of marbling in the meat. This statement agrees with our finding that the loin and entrecote of the $\mathrm{Hf}$ bulls had a clearly higher marbling score than those of the Ch bulls. In the present study, the bulls were slaughtered at high $\mathrm{CW}$ and high shear force values obtained correspond with tough meat. It is suggested that the taste of beef will strengthen when animals get older and heavier, but meat will become also tougher due to the strengthening of collagen structure (Lawrie \& Ledward, 2006). Therefore, longer ageing period would be necessary in meat from animals slaughtered at high LW.

In general, the feeding treatments had no important effects on meat quality characteristics of the Longissimus muscle. These results are broadly in agreement with those reported by Keady et al. $(2007,2008)$ that concentrate level has no remarkable effect on meat quality of finishing cattle. It is well established that muscle colour is generally darker in forage-fed than in concentrate-fed animals (e.g. Caplis et al. 2005). However, in the present study the muscle lightness ( $L$ value) was higher for the $M$ bulls than for the $L$ bulls and the explanation for this effect is not clear. In accordance with our results, Caplis et al. (2005) reported no effects on muscle redness (a value) and yellowness (b value) between concentrate proportions 310 and $550 \mathrm{~g} \mathrm{~kg}^{-1} \mathrm{DM}$. In agreement with the present study, Manninen et al. (2011) reported that protein supplementation had no effect on the shear force value, $\mathrm{pH}$ or sensory characteristics in beef bulls.

The present results suggest that $\mathrm{Hf}$ bulls produced healthier meat with a lower $n-6 / n-3$ fatty acid ratio and higher MUFA concentration compared to Ch bulls. Breed differences and associated effects of maturity or growth potential on the subcutaneous or intramuscular fatty acid composition of beef are extensively discussed in the review by de Smet et al. (2004). It is possible that the differences in carcass fat score between breeds in the present experiment ( 4.5 vs. 2.9 for $\mathrm{Hf}$ and Ch bulls, respectively) affected also the differences in the fatty acid composition of the longissimus muscle. According to de Smet et al. (2004), carcass fat score affects the fatty acid profile of the meat, and breed differences reported in the literature are often confounded by differences in fatness as in the present experiment. Nevertheless, specific breed differences in the $n-6 / n-3$ fatty acid ratio and in the levels of longer chain fatty acids that probably could not be attributed to differences in the fat level have also been reported (de Smet et al. 2004), but many of these breed differences are relatively small and are, although often statistically significant, probably of little value from a nutritional viewpoint.

Our results are mainly in accordance with Daley et al. (2010) who concluded that increasing the concentrate level generally increases the $n-6 / n-3$ fatty acid ratio of the longissimus muscle. A healthy diet should consist of roughly one to four times more omega- 6 fatty acids than omega- 3 fatty acids. The review by Daley et al. (2010) shows significant difference in the $n-6 / n-3$ fatty acid ratio between grass-fed and grain-fed beef, with an overall average of 1.53 and 7.65 for grass-fed and grain-fed, respectively, for all the studies reviewed. In our study, $n-6 / n-3$ fatty acid 
ratios for $L$ and $M$ feedings were 3.16 and 5.03, respectively. Furthermore, Daley et al. (2010) reported that grainfed beef consistently produces a lower concentration of 18:3 cis-9,cis-12,cis-15 fatty acid and higher concentrations of MUFAs as compared to grass-fed beef, which includes fatty acids such as 18:1 cis-9, the primary MUFA in beef. These findings are in line with the present results.

Limitation of present study is that the breed effects are partly confounded with carcass weight because the target for average carcass weight was different for $\mathrm{Hf}$ and $\mathrm{Ch}$ bulls. However, the targeted carcass weights are nowadays the average weights for slaughtered bulls of these breeds in Finland. Therefore, the present results are valid from a practical point of view.

\section{Conclusions}

In conclusion, breed differences in growth performance and carcass traits were observed when the bulls were slaughtered at typical Finnish carcass weights; 380 and $420 \mathrm{~kg}$ for $\mathrm{Hf}$ and Ch bulls, respectively. The later maturing Ch bulls tended to achieve higher weight gain, produced less fat and had a higher percentage of their meat in high-priced joints compared to the earlier maturing $\mathrm{Hf}$ bulls. On the other hand, $\mathrm{Ch}$ had a lower degree of marbling in their meat compared to $\mathrm{Hf}$. The growth performance of the bulls increased with increasing concentrate level and increasing the concentrate allowance also improved carcass conformation. However, also higher slaughter weights with increasing concentrate level probably partly explained some differences in carcass traits between the concentrate proportions. In general, rapeseed meal supplementation had limited effects on the performance, carcass traits or meat quality. According to this study, the choice of breed and feeding can affect the composition of the intramuscular fat. The results indicate that Hf bulls produced healthier meat with a lower $n-6 / n-3$ fatty acid ratio and higher MUFA concentration compared to Ch bulls. In addition increasing the concentrate level increased the $n-6 / n-3$ fatty acid ratio of the longissimus muscle.

\section{Acknowledgements}

This study was partially funded by the Centre for Economic Development, Transport and the Environment for Northern Ostrobothnia. We would like to thank Mr. Lauri Jauhiainen for advice on the statistical analyses. We wish to express our gratitude also to Mr. Matti Huumonen and his personnel for technical assistance and their excellent care of the experimental animals. The personnel of the Slaughterhouse of Atria in Kuopio and the staff of the Finnish Meat Research Institute in Hämeenlinna are thanked for their help in slaughter procedures and meat evaluation. The personnel at Animal Production Research in Jokioinen are thanked for the laboratory analyses.

\section{References}

Aass, L. \& Vangen, O. 1998. Carcass and meat quality characteristics of young bulls of Norwegian cattle and crossbreds with Angus, Hereford and Charolais. Acta Agriculturae Scandinavica, Section A, Animal Science 48: 65-75.

AOAC. 2002. AOAC official method 996.06, fat (total, saturated, and unsaturated) in foods, hydrolytic extraction gas chromatographic method. First action 1996, revised 2001, AOAC international 2002. Cited 3 July.2012. Available on the Internet: http:// files.instrument.com.cn/bbs/upfile/2008622221856.pdf

Alberti, P., Panea, B., Sañudo, C., Olleta, J.L., Ripoll, G., Ertbjerg, P., Christensen, M., Gigli, S., Failla, S., Concetti, S., Hocquette, J.F., Jailler, R., Rudel, S., Renend, G., Nute, G.R., Richardson, R.I. \& Williams, J.L. 2008. Live weight, body size and carcass characteristics of young bulls of fifteen European breeds. Livestock Science 114: 19-30.

Aronen, I. 1992. Quality of Supplementary Feed Protein for Growing Cattle. Academic dissertation. Faculty of Agriculture and Forestry of the University of Helsinki, Helsinki, Finland. 46 p.

Ashmore, C.R. \& Vigneron, P. 1988. Biological bases of carcass and meat quality and their relationships with growth. Proceedings of the $3^{\text {rd }}$ World Congress of Sheep and Beef Cattle Breeding. Paris, 19-23 June. p. 381-393.

Bartoň, L., Řehák, D., Teslík, V., Bureš, D. \& Zahrádková, R. 2006. Effect of breed on growth performance and carcass composition of Aberdeen Angus, Charolais, Hereford and Simmental bulls. Czech Journal of Animal Science 51: 47-53.

Bureš, D., Bartoň, L., Zahrádková, R., Teslík, V. \& Krejčová, M. 2006. Chemical composition, sensory characteristics, and fatty acid profile of muscle from Aberdeen Angus, Charolais, Simmental, and Hereford bulls. Czech Journal of Animal Science 51: 279-284.

Caplis, J., Keane, M.G., Moloney, A.P. \& O'Mara, F.B. 2005. Effects of supplementary concentrate level with grass silage, and separate or total mixed ration feeding, on performance and carcass traits of finishing steers. Irish Journal of Agricultural and Food Research 44: 27-43.

Daley, C. A., Abbott, A., Doyle, P. S., Nader, G. A. \& Larson, S. 2010. A review of fatty acid profiles and antioxidant content in grassfed and grain-fed beef. Nutrition Journal 9: 1-12. 
De Smet, S., Raes, K. \& Demeyer, D. 2004. Meat fatty acid composition as affected by fatness and genetic factors: a review. Animal Research 53: 81-98.

Drennan, M.J., Moloney, A.P. \& Keane, M.G. 1994. Effects of protein and energy supplements on performance of young bulls offered grass silage. Irish Journal of Agricultural and Food Research 33: 1-10.

EC 2006. Council Regulation (EC) No 1183/2006 of 24 July 2006 concerning the Community scale for the classification of carcasses of adult bovine animals. The Official Journal of the European Union L, 214: 1-6.

Gregory K.E., Cundiff L.V., Koch R.M., Dikeman M.E. \& Koohmaraie M. 1994. Breed effects and retained heterosis for growth, carcass, and meat traits in advanced generations of composite populations of beef cattle. Journal of Animal Science 72: 833-850.

Hagemeister, H., Lüpping, W. \& Kaufmann, W. 1980. Microbial protein synthesis and digestion in the high-yielding dairy cow. In: Haresign, W. (ed.). Recent Advances in Animal Nutrition - 1980. London, UK: Butterworths. p. 67-84.

Honkavaara, M., Rintasalo, E., Ylönen, J. \& Pudas, T. 2003. Meat quality and transport stress of cattle. Deutsche Tierärztliche Wochenschrift 110: 125-128.

Huhtanen, P. \& Jaakkola, S. 1993. The effects of forage preservation method and proportion of concentrate on digestion of cell wall carbohydrates and rumen digesta pool size in cattle. Grass Forage Science 48: 155-165.

Hussein, H.S. \& Jordan, R.M. 1991. Fish meal as a protein supplement in ruminant diets: a review. Journal of Animal Science 69: 2147-2156.

Huuskonen, A. 2009a. Concentrate feeding strategies for growing and finishing dairy bulls offered grass silage-based diets. MTT Science 1. 99 p. (Doctoral Dissertation).

Huuskonen, A. 2009b. The effect of cereal type (barley versus oats) and rapeseed meal supplementation on the performance of growing and finishing dairy bulls offered grass silage-based diets. Livestock Science 122: 53-62.

Huuskonen, A. 2011. Effects of barley grain compared to commercial concentrate or rapeseed meal supplementation on performance of growing dairy bulls offered grass silage-based diet. Agricultural and Food Science 20: 191-205.

Huuskonen, A., Joki-Tokola, E., Honkavaara, M., Tuomisto, L. \& Kauppinen, R. 2010. Meat quality and fatty acid profile of M. longissimus dorsi of growing bulls under insulated, uninsulated and outdoor housing conditions. Agricultural and Food Science 19: 214-222.

Huuskonen, A., Khalili, H. \& Joki-Tokola, E. 2007. Effects of three different concentrate proportions and rapeseed meal supplement to grass silage on animal performance of dairy-breed bulls with TMR feeding. Livestock Science 110: 154-165.

Huuskonen, A., Khalili, H. \& Joki-Tokola, E. 2008a. Inclusion of barley fibre and barley protein in a total mixed ration for growing dairy bulls. Acta Agriculturae Scandinavica, Section A, Animal Science 58: 37-44.

Huuskonen, A., Khalili, H. \& Joki-Tokola, E. 2008b. Need for protein supplementation in the diet of growing dairy bulls fed total mixed ration based on moderate digestible grass silage and barley. Agricultural and Food Science 17: 109-120.

Huuskonen, A., Pesonen, M., \& Hyrkäs, M. 2012. Liharotuisten sonnien ja hiehojen kasvu- ja teurasominaisuudet. Suomen Maataloustieteellisen Seuran Tiedote 29, 84 (Abstract). (in Finnish).

Jaakkola, M., Korpelainen, V., Hoppula, K. \& Virtanen, V. 2012. Chemical composition of ripe fruits of Rubus chamaemorus L. grown in different habitats. Journal of the Science of Food and Agriculture 92: 1324-1330.

Jaakkola, S., Huhtanen, P. \& Vanhatalo, A. 1990. Fermentation quality of grass silage treated with enzymes or formic acid and nutritive value in growing cattle fed with or without fish meal. Acta Agriculturae Scandinavica 40: 403-414.

Jaakkola, S., Kaunisto, V. \& Huhtanen, P. 2006. Volatile fatty acid proportions and microbial protein synthesis in the rumen of cattle receiving grass silage ensiled with different rates of formic acid. Grass and Forage Science 61: 282-292.

Kaminiecki, H., Wójcik, J., Pilarczyk, R., Lachowicz, K., Sobczak, M., Grzesiak, W. \& Błaszczyk, P. 2009. Growth and carcass performance of bull calves born from Hereford, Simmental and Charolais cows sired by Charolais bulls. Czech Journal of Animal Science 54: 47-54.

Karhula, T. \& Kässi, P. 2010. Lihanautatilojen taloudellinen tilanne Suomessa ja vertailumaissa. In: Huuskonen, A. (ed.). Kehitystä naudanlihantuotantoon I. (Towards More Efficient Beef Production I). Tampere, Finland: Tampereen yliopistopaino Juvenes Print Ltd,. p. 9-34. (In Finnish with English Abstract).

Keady, T.W.J. \& Kilpatrick, D.J. 2006. The effect of forage: concentrate ratio on the performance of bulls slaughtered at a range of live weights. Proceedings of the British Society of Animal Science. British Society of Animal Science. p. 50.

Keady, T.W.J., Lively, F.O., Kilpatrick, D.J. \& Moss, B.W. 2007. Effects of replacing grass silage with either maize or whole-crop wheat silages on the performance and meat quality of beef cattle offered two levels of concentrates. Animal 1: 613-623.

Keady, T.W.J., Lively, F.O., Kilpatrick, D.J. \& Moss, B.W. 2008. The effects of grain treatment, grain feed level and grass silage feed value on the performance of and meat quality from, finishing beef cattle. Animal 2: 149-159.

Keane, M.G. 2010. A comparison of finishing strategies to fixed slaughter weights for Holstein Friesian and Belgian Blue $\times$ Holstein Friesian steers. Irish Journal of Agricultural and Food Research 49: 41-54.

Keane, M.G. \& Allen, P. 1998. Effects of production system intensity on performance, carcass composition and meat quality of beef cattle. Livestock Production Science 56: 203-214.

Keane, M.G., Drennan, M.J. \& Moloney, A.P. 2006. Comparison of supplementary concentrate levels with grass silage, separate or total mixed ration feeding, and duration of finishing in beef steers. Livestock Science 103: 169-180.

Keane, M.G. \& Fallon, R.J. 2001. Effects of feeding level and duration on finishing performance and slaughter traits of HolsteinFriesian young bulls. Irish Journal of Agricultural and Food Research 40: 145-160. 
Kempster A.J., Cook G.L. \& Southgate J.R. 1982. A comparison of the progeny of British Friesian dams and different sire breeds in 16- and 24-month beef production systems. 2. Carcass characteristics, and rate and efficiency of meat gain. Animal Production 34: 167-178.

Kempster A.J., Cook G.L. \& Southgate J.R. 1988. Evaluation of British Friesian, Canadian Holstein and beef breed $\times$ British Friesian steers slaughtered over a commercial range of fatness from 16-month and 24-month beef production systems. 2. Carcass characteristics, and rate and efficiency of lean gain. Animal Production 46: 365-378.

Khalili, H \& Huhtanen, P. 1991. Sucrose supplements in cattle given grass silage-based diets. 2. Digestion of cell wall carbohydrates. Animal Feed Science and Technology 33: 263-273.

Klopfenstein, T.J. \& Erickson, G.E. 2002. Effects of manipulation of protein and phosphorus nutrition of feedlot cattle on nutrient management and the environment. Journal of Animal Science 80 (E. Supplement 2): E106-E114.

Lawrence, T., Fowler, V. \& Novakofski, J. 2012. Growth of farm animals. CAB International, Wallingford, UK. 368 p.

Lawrie, R.A. \& Ledward, D.A. 2006. Lawrie's Meat Science. $7^{\text {th }}$ edition. Woodhead Publishing Limited, Abington Hall, Abington, Cambridge, England. 521 p.

MAFF. 1984. Energy Allowances and Feeding Systems for Ruminants. ADAS Reference book 433. Ministry of Agriculture, Fisheries and Food. Her Majesty`s Stationery Office, London. 85 p.

Manninen, M., Honkavaara, M., Jauhiainen, L., Nykänen, A. \& Heikkilä, A.-M. 2011. Effects of grass-red clover silage digestibility and concentrate protein concentration on performance, carcass value, eating quality and economy of finishing Hereford bulls reared in cold conditions. Agricultural and Food Science 20: 151-168.

Manninen, M., Jauhiainen, L., Ruusunen, M., Soveri, T., Koho, N., \& Pösö, R. 2010. Effects of concentrate type and level on the performance and health of finishing Hereford bulls given a grass silage-based diet and reared in cold conditions. Livestock Science 127: 227-237.

Martinsson, K. 1990. The effects of forage digestibility and concentrate supplementation on performance of finishing bulls. Swedish Journal of Agricultural Research 20: 161-167.

McNamee, B.F., Kilpatrick, D.J., Steen, R.W.J. \& Gordon, F.J. 2001. The prediction of grass silage intake by beef cattle receiving barley-based supplements. Livestock Production Science 68: 25-30.

Minson, D.J. 1982. Effect of chemical composition on feed digestibility and metabolizable energy. Nutrition Abstracts and Reviews 52: 591-615.

MTT. 2012. Feed tables and nutrient requirements. Jokioinen: MTT Agrifood Research Finland. Cited 1May 2012). Available on the Internet: http://www.mtt.fi/feedtables

Patterson, D.C., Steen, R.W.J., Moore, C.A. \& Moss, B.W. 2000. Effects of the ratio of silage to concentrates in the diet on the performance and carcass composition of continental bulls. Animal Science 70: 171-179.

Polách, P., Šubrt, J., Bjelka, M., Uttendorfský, K. \& Filipčík, R. 2004. Carcass value of the progeny of tested beef bulls. Czech Journal of Animal Science 49: 315-322.

Randby, Å.T., Nørgaard, P. \& Weisbjerg, M.R. 2010. Effect of increasing plant maturity in timothy-dominated grass silage on the performance of growing/finishing Norwegian Red bulls. Grass and Forage Science 65: 273-286.

Razminowicz, R.H., Kreuzer, M. \& Scheeder, M.R.L. 2006. Quality of retail beef from two grass-based production systems in comparison with conventional beef. Meat Science 73: 351-361.

Sinclair, K.D., Lobley, G.E., Horgan, G.W., Kyle, D.J., Porter, A.D., Matthews, K.R., Warkup, C.C. \& Maltin, C.A. 2001. Factors influencing beef eating quality -1 . Effects of nutritional regimen and genotype on organoleptic properties and instrumental texture. Animal Science 72: 269-277.

Steen, R.W.J., Kilpatrick, D.J. \& Porter, M.G. 2002. Effects of the proportions of high or medium digestibility grass silage and concentrates in the diet of beef cattle on liveweight gain, carcass composition and fatty acid composition of muscle. Grass and Forage Science 57: 279-291.

Van Keulen, J. \& Young, B.A. 1977. Evaluation of acid-insoluble ash as a marker in ruminant digestibility studies. Journal of Animal Science 44: 282-287.

Van Koevering M.T., Gill D.R., Owens F.N., Dolezal H.G. \& Strasia C.A. 1995. Effect of time on feed on performance of feedlot steers, carcass characteristics, and tenderness and composition of longissimus muscles. Journal of Animal Science 73: 21-28.

Warris, P.D. 1996. Instrumental measurement of colour. In: Taylor, S.A., Raimundo, A., Severini, M. \& Smulders, F.J.M. (eds.). Meat quality and meat packaging. Utrect, The Netherlands: ECCEAMST. p. 221-232.

Wheeler, T.L., Cundiff, L.V., Koch, R. \& Crouse, J.D. 1996. Characterization of biological types of cattle (Cycle IV): Carcass traits and longissimus palatability. Journal of Animal Science 74: 1023-1035. 